of glaciers with dark frowning and flat-topped cliffs, here and there reaching to a height of 1200 feet. It was after passing Barents' Hook that new ground was actually broken, and the exploration was continued westwards until Mr. Smith succeeded in rounding the western headland. The farthest point actually reached by the Eira was in N. lat. $82^{\circ} 20^{\prime}$, E. long. $45^{\circ}$, and thence the land could be seen trending away to the north-west. During the voyage a meteorological record was kept, photographs taken, and various collections made, chiefly of botanical and geological specimens.

THe January number of Petermann's Mittheilungen contains an accouni of a journey from Dufile to Lur, on the west shore of Lake Mwutan-Nzige, by Dr. Emin Bey, in the last months of I879. Herr Clemens Denhardt brings together much valuable information on the East African region between Mombasa and the Victoria Nyanza, with special reference to the trade-routes, accompanied by an excellent map. An article of special scientific interest is contributed by Dr. H. Hoffmann on the Comparative Phænology of Central Europe. In a series of tables and in a map the average time of bloom is shown for a very large number of places, with reference to Giessen as a standard. There is a very interesting account by Baron Nordenskjöld of his visit to Behring Island, followed by some critical remarks on the vegetative region of the Serra da Estrella, by Dr. O. Drude.

Bulletin, No. 5, 1879, of the American Geographical Society contains a paper by General R. E. Colston on "Life in the Egyptian Deserts," and an amusing lecture by Lord Dunraven on "Moose and Caribos Hunting."

THE French station of the African Association has been esta. blished by M. Savorgnan de Brazza at Nghimi, on the route from Machogo to Levumba, in the region of the sources of the Ogové, in $\mathrm{I}^{\circ} 30^{\prime} \mathrm{S}$., and about $\mathrm{II}^{\circ} \mathrm{E}$. from Paris.

THE publication in which the results of the determination of the South American longitudes by electricity have been tabulated by American observers has just arrived in Paris. All the positions determined by M. Mouchez on the Brazilian coast have proved correct within a difference of $I \frac{1}{2}$ second of time. These determinations were taken by Admiral Mouchez when a subordinate officer in the French service twenty years ago, by lunar distances, occultations, and eclipses.

THE author of the summary of Geographical Discovery in Whitaker's Almanac writes to us in reference to the notice on p. 232, that it is not stated that Mr. Leigh Sr. ith's voyage is "the most remarkable geographical event of the year," to the depreciation of Mr. Thomson's African journey ; "but that, in spite of the success of the latter, Mr. Smith's voyage would probably be considered by many as the most remarkable geographical event of I880." We doubt if "many" would hold such an opinion, merely for the reason assigned in the Almanac. "May I be allowed to point out," he adds, " that the word 'research' means careful search or investigation? and that mere searching for the North Pole is not the sole object of Arctic voyages?" We are glad the writer is of this opinion, though we doubt if Mr. Leigh Smith's voyage has much bearing on Polar "research."

\section{CHESAPEAKE ZOOLOGICAL LABORATORY}

\section{$A$ REPORT of the third year's work at the Chesapeake Zoo-} logical Laboratory of the Johns Hopkins University has been addressed to the President of the University by Mr. W. K. Brooks, Director of the Laboratory. An advance copy of this has been sent us, from which we make some valuable extracts.

The laboratory was opened at Beaufort, North Carolina, on April 23, 1880, and closed on September 30, after a session of twenty-three weeks. It was supplied with working accommodations for six investigators, and the facilities which it afforded were used by the following six persons :-W. K. Brooks, Ph.D., Director; K. Mitsukuri, Ph.B., Fellow in Biology ; E. B. Wilson, Ph.B., Fellow in Biology; F. W. King, A.M., Professor of Natural Science, Wisconsin State Normal School; H. C. Evarts, M.D., Academy of Natural Sciences, Philadelphia H. F. Osborne, Ph.D., Fellow of the College of New Jersey.

Beaufort was selected for the third season's work because it is the nearest accessible town south of Baltimore which is favourably situated for zoological study. The scientific advantages of Beaufort are very great; the most important is the great difference between its fauna and that of the northern Atlantic coast.

"The configuration of our coastline," the Report goes on, "is such that Cape Hatteras, the most projecting point south of New York, deflects the warm water of the Gulf Stream away from the coast, and thus forms an abrupt barrier between a cold northern coast and a warm southern one. The fauna north of this barrier passes gradually into that of southern New England, while the fauna south of the barrier passes without any abrupt change into that of Florida, but the northern fauna is sharply separated by Cape Hatteras from the southern. As the laboratory of the U.S. Fish Commission and Mr. Agassiz's laboratory at Newport afford opportunities for work upon the northern fauna, it seemed best for us to select a point south of Cape Hatteras in order to study the southern fauna with the same advantages, and as Beaufort is the only town near the Cape which can be reached without difficulty, it was chosen as the best place for the laboratory. The situation of this town is exceptionally favourable for zoological work, for the surrounding waters present such a diversity of conditions that the fauna is unusually rich and varied."

After describing in detail the special characteristics of the locality Mr. Brooks goes on to say :

"The zoological resources of Beaufort have not escaped the attention of American naturalists, and there are few places upon our coast, outside of New England, where more zoological work has been done. In 1860 Drs. Stimpson and Gill spent a season in dredging and collecting in the vicinity of Beaufort, Cape Lookout, and Cape Hatteras, and an account of their work was published in the American Journal of Science. Dr. Coues, who was stationed at Fort Macon during the war, occupied himself for two years in collecting the animals which are found here, and he published a series of papers on the 'Natural History of Fort Macon and Vicinity' in the Proceedings of the Academy of Natural Sciences of Philadelphia. These papers, which were continued by Dr. Yarrow, contain copious and valuable notes on the habits and distribution of the animals which were cbserved, and we found them a great help to us. These two naturalists found 480 species of animals in the vicinity of Beaufort. Of these 480,298 are vertebrates, and 182 are invertebrates. Of the vertebrates 24 are mammals, 133 are birds, 27 are reptiles, 6 batrachians, 97 fishes, and I I selachians. Of the invertebrates I47 are mollusks, $2 \mathrm{I}$ are crustaceans. The list of vertebrates is very nearly exhaustive, and we made no additions to it; but the list of invertebrates is obviously very imperfect, and although we made no attempt to tabulate the species which we observed, there would be no difficulty in enlarging the list twenty or thirty fold.

"Among other naturalists who have spent more or less time at Beaufort I may mention Prof. L. Agassiz, Prof. E. S. Morse, Dr. A. S. Packard. Prof. Webster, and Prof. D. S. Jordan. Prof. Morse procured most of the material for his well-known paper on the Systematic Position of the Brachiopoda on the Sand-bars in Beaufort Inlet.

"I will now attempt to give a very short statement of some of the leading points in our own summer's work. Much of our time was spent in studying the development of the Crustacea, since this is one of the most important fields for original work upon our southern coast. The supply of material is almost inexhaustible, and would employ a number of students for many years. The life-history of the Crustacea is of great interest in itself, and the recent species are so numerous and diversified that there is no group of animals better adapted for studying the general laws of embryonic development in their relation to the evolution of the group. These considerations have led us to devote especial attention to this group during this and the preceding seasons. One of the published results of the first season's work was an illustrated account of the metamorphosis of Squilia, a representative of a somewhat aberrant group of Crustacea. During the second season a member of our party, Prof. Birge, made a very thcrough study of the development of Panopæus, one of our crabs, and the account of his observations, with drawings, was ready for publication several months ago. At Beaufort we spent most of our time upon this subject, and figured more than 800 points in the development of various Crustacea.

"Among these I wish to call especial attention to our obser. vations upon the development of the Sergestidæ; the least specialised of the stalk-eyed Crustacea. This very peculiar group was not known to occur upon our coast until we found a few 
specimens of one genus at Fort Wool, and the same genusLucifer-in great abundance at Beaufort, associated with another genus which is also new to North America. As nothing whatever was known of the development of Lucifer, we made every effort to obtain the eggs and young, and after four months of almost fruitless labour we finally succeeded in finding all the stages of the metanorphosis, and figured them in a complete series of ninety-nine drawings. We also obtained a somewhat less complete series of figures of stages in the life history of the second Sergestid. Our only motive in this work was the desire to fill a gap in our knowledge of crustacean development by supplying the life-history of a very interesting group of animals, but the result was found to have a very unexpected value, since it contributes to the discussion of a number of problems in general embryology and morphology, and is the most significant crustacean life history which has ever been studied.

"The following are some of the more important points:The egg undergoes total regular segmentation. There is no food-yolk, and cleavage goes quite through the egs. There is a true segmentation cavity. Segmentation is rhythmical. There is an invaginate gastrula. The larva leaves the egg as a Nauplius, and passes through a protozoea stage and a schizopod stage. The fifth thoracic segments and appendages are entirely wanting at all stages of development.

"Another interesting group which was studied is the Porcellanidæ; the least specialised of the true crabs. The adults of our American species are almost restricted to our southern waters, although the swimming larvæ are carried north by the Gulf Stream. Within the last two years two northern naturalists have studied these floating embryos upon the south coast of New England, but as they were working upon stragglers s? far from home, their accounts are incomplete and somewhat contradictory. Our advantages at Beaufort enabled us to contribute towards the solution of this confused subject by raising one species of Porcellana from the egg. We also raised six other species of crabs from the egg, and made drawings of the more important stages of development. One of the species which was thus studied is the edible crab. Its metamorphosis has never been figured, and although it presents no unusual features, its economic importance gives value to exact knowledge of its life history. Mr. Wilson also studied the development of one species of Pycnogonida, a group of very peculiar Arthropods distantly related to the spiders. As he has paid especial attention to the systematic study of this group, and is now engaged in describing the Pycnogonids collected in the Gulf Stream by Mr. Agassiz, the opportunity to study them alive in the laboratory has been a great advantage to him.

"Another important investigation is the study by Mr. IVilson of the embryology of the marine Annelids. Although the representatives of this large group are abundant and widely distributed, little was known of the early stages of their development until he procured the egg. of several species and studied them at Beaufort. This investigation has shown, among other things, that the accepted division of Annelids into two great groups, the Oligochæta and Polychæta, is not a natural method of classification. The work upon the development of marine Annelids was supplementary to an investigation which $\mathrm{Mr}$. Wilson carried on last spring at Baltimore, and which he will continue this winter, upon the development of land-and freshwater Annelids.

"As much time as po:sible was given this season to the study of the hydroids and jelly-fish of Beaufort. The life history of several of them were investigated, a thorough anatomical study of some of the most important forms was carried $\mathrm{cn}$, and nearly two hundred drawings was made. It is almost impossible to complete a study of this kind in a single season, but if one or two more summers can be given to the work, we have every reason to hope for valuable results, for although the North Carolina coast is the home of many species which are only found as stragglers upon our northern coast, and of other species which are not known to occur anywhere else, and of some genera and families which are new to the North American coast, this field has suffered almost total neglect.

"Nearly three months of the time of two members of our party, Mitsukuri and Wilson, were given to the study of the habits, anatomy, and development of Renilla, a compound Polyp very much like that which forms the precious coral, but soft and without a stony skeleton. The animais which form the community are so intimately bound together that the community as a whole has a well-marked individuality distinct from that of the separate animals which compose it. The compound individuality of Renilla is quite rudimentary as compared with that of a Siphonophore, and as there is no trace of it in the closely allied Gorgonias, it furnishes an excellent field for studying the incipient stages in the formation of a compound organism by the union and specialisation of a community of independent simple organisms. With this end in view the anatomy of the fullydeveloped community was carefully studied, and the formation of a community was traced by rearing a simple solitary embryo in an aquarium until a perfect community had been developed from it by budding. During the process of development the law of growth by which the characteristics of the compound organism are brought about was very clearly exhibited, and it is fuliy illustrated by nearly one hundred drawings.

"One of the most interesting results of our work is the explanation by Mr. Wilson of the origin of the metamorphosis of the larva of Phoronis, a small Gephyrean worm which lives in a tube. Several of the most noted embryologists of Europe have studied the development of Phoronis, and our knowledge of its life history is due to their combined labours. Last summer Mr. Wilson reviewed the subject, and added some important points, and during the present season he has shown by the comparison of a great number of allied forms that the very peculiar meta. morphosis admits of an extremely simple explanation. The adult is sedentary and confined to its sand tube, while the larva is a swimming animal totally different in structure. The change from the larva to the adult is very rapid and violent. It occupies only a few minutes, and during the change the larva becomes turned wrong side out, so that what was internal is external, Mr. Wilson's comparison shows that Phoronis was originally a free animal, and that the structural peculiarities which fit the adult for sedentary life in a tube are of recent acquisition. The larva has however retained its ancestral adaptation to a swimming life in order to provide for the distribution of the srecies. There must have been a time, in the evolution of the species, when the adult was imperfectly adapted to a sedentary life, and also imperfectly adapted to a swimming life ; and if the development of the individual were a perfect recapitulation of all the stages in the evolution of the species, we should have, between the swimming larva and the sedentary adult, a stage of development during which the adaptation is not quite perfect for either mode of life. It is clearly an advantage for the airimal to pass through this stage as quickly as possible, or to escape it altogether. The peculiar metamorphosis enables the larva to remain perfectly adapted to a locomotor life until the occurrence of the sudden change which fits it for life in a tube; and $\mathrm{Mr}$. Wilson has pointed out the manner in which the metamorphosis has been acquired in order to bridge over the period of imperfect specialisation. This explanation is somewhat similar to that which Lubbock has given of the origin of the metanorpbosis of insects, and we may hope that the same method of investigation will throw light upon the significance of other remaikable instances of metamor ho is in the invertebrates.

"During the summer the following abstracts of some of the more important points in our work have been published in scientific journals :-

The Development of the Cephalopoda and the Homology of the Cephalopod Foot. By W. K. Brocks. Amer. Journal of Science.

The Development of Annelids. By E. B. Wilson. Amer. Journal of Science.

The Rhythmical Nature of Segmentation. By W. K. Brooks. Amer. Journal of Science.

The Origin of the Metamorphosis of Actinotrocha. By E. B. Wilson. Amer. Assoc., Boston Meeting.

Notes on the Medusæ of Beaufort. By W. K. Brooks. Amer. Assoc., Boston Meeting.

Budding in Free Medusæ. By W. K. Brooks. Amer. Nat.

Development of Marine Polychætous Annelids. By E. B. Wilson. Zoölogischer Anzeiger.

Embryology and Metamorphosis of Lucifer. By W. K. Brooks. Zoölogischer Anzeiger.

The Early Stages of Renilla. By E. B. Wilson. Amer. Journal of Science.

"Other abstracts are now in the press, and others are ready for publication.

"A paper, with four plates, on the "Early Stages of the Squid,' is also in the press, and will soon be issued in the Memorial Volume of Memoirs of the Boston Society of Natural History." 